\title{
THE SPECIFIC CHARACTER TRAITS OF YOUNG ENTREPRENEURS IN SLOVAKIA
}

\author{
Monika SOBEKOVÁ MAJKOVÁ, Aleksandr KLJUČNIKOV
}

\begin{abstract}
Worldwide scientific researches present the entrepreneurs have to declare specific characteristic traits to be successful in the business. This paper is focused on the comparison of the specific character traits between potential young entrepreneurs and other young people. The aim is to compare the three chosen character traits differences between these two focus groups by using the statistical method of Pearson's chi-square and bring the answers on the questions why some people incline to becoming the entrepreneurs more intensively than others, and what are the differences between them in relation to the character traits and their personality characteristics. The research was conducted among 1233 young people in all regions of Slovakia in 2012. The results show, that young people who plan to become an entrepreneur, are more creative, willing to face the risk, more confident in the solvation of complicated problems and difficult tasks with the opposite group of respondents.
\end{abstract}

\section{KEY WORDS}

entrepreneurial traits, character traits, personal qualities of entrepreneurs, potential entrepreneurs, young entrepreneurs

\section{JEL CODE}

G11, G32

\section{INTRODUCTION}

Slovak, Czech and other foreign researchers (e.g. Belás at al. 2016, Deáková et al. 2010, Korauš at al.2015, Frese and Gielnik, 2014, Mura and Machová, 2015, Sidik, 2012, Sharma, Bozatzis and Jain, 2011, Tu et al., 2012, Soomro and Shah, 2015, Hvide and Panos, 2014, Knörr et al., 2013 and Soininen et al., 2012, Košičiarová and Vincúrová, 2015 etc.) state that entrepreneurs have to have special personal qualities and characteristics to be successful in business. Sobeková et al. (2015) along with many other authors declare that entrepreneurs and SMEs are an important part of each market economy. But what about the young people who decided to become an entrepreneur? Can we identify the same character traits in their case or not? In this paper we have collected the evidence that may bring the answer on this fundamental question. The research, conducted in 2012 among more than twelve hundred young people in Slovakia, was aimed to prove that in relation to the chosen character traits potential young entrepreneurs are significantly different than people without entrepreneurial ambitions. The research team formulated a hypothesis that there are statistically significant differences in character traits of potential young entrepreneurs and other 
young people. The aim of the research was to find solid statistical evidence to prove this statement. Statistical method of Pearson's chi-square statistics was used for its verification.

\section{$1 \quad$ Literature Review}

The authors Sharma, Bozatzis and Jain (2011, p. 125) present the thought there may be no entrepreneurship without an entrepreneur. Due to the missing special individual personality features that are necessary for entrepreneurship not every person can or will become an entrepreneur. People without entrepreneurial ambitions may have a lack of psychological attributes, social functions and situational factors. The framework of the potential entrepreneur abilities and description of the entrepreneurial behaviour created by earlier research studies describes the entrepreneurship as a multidimensional process, and the character traits belong to its components. The researchers found that despite of the existence of favourable factors, a potential entrepreneur might decide not to exploit entrepreneurial opportunity; certain people act differently than others in exactly the same situation. We suppose that they act differently than others exactly because of the special character traits.

Behaviour in business is determined by many factors and character traits are one of the most important. Deáková et al. (2010) considers such features and capabilities as self - reliance, courage, responsibility, determination, creativity, scholarship and perseverance as the most important personal qualities of the entrepreneurs. It is necessary to look for specific knowledge and behaviours to increase the efficiency of administrative and production processes in a private company (Dobrovič at al., 2016). According to Belás et al. (2013) the entrepreneurs' personal characteristics are very important in relation to the financial performance of the company.

According to Frese and Gielnik (2014) the entrepreneurs should have several personal traits that make them capable to act as the entrepreneur, investor, marketing specialist, seller etc. Soomro and Shah (2015) in their study declare that knowledge, skills and attitudes belong to the main characteristics of the potential entrepreneurs.Sidik (2012) confirms that entrepreneurs tend to manage their businesses by using strong and specific personal qualities. Delgado - García et al. (2012) proved on the sample of 335 entrepreneurs from the multiple industry fields in Spain that entrepreneurs' emotions and traits have the impact on the company goals. Esfahani and Pour (2013) presented the study about the effects of entrepreneurial characteristics of educational managers on the innovativeness of school organization. In their study they observed such entrepreneurial characteristics as: creativity, risk, seeking of challenges and ambiguity tolerance. Their findings indicate that such factors as the ownership status of schools and challenge seeking traits are significantly related to the innovativeness of school organizations.

Misra and Kumar (2000) brought a proposal of the framework describing the psychological profile of the entrepreneur and his behaviour, while Sharma, Boyatzis and Jain (2011) based on more than ten years lasting research study summarized the entrepreneur's attitudes and personal characteristics as follows: innovativeness, creativity, proactivity, risk-taking propensity, internal locus of control, self-efficacy, tolerance for ambiguity, social intelligence, extraversion, miscellaneous competencies.

The first observed character trait in the research was the ability to take the risk. Kozubíková et al. (2015) examined the relationship between personality characteristics and approach to the perception and management of business risks. The results of their study showed a high level of confidence of individual groups of entrepreneurs in evaluation of their ability to manage financial risk and high intensity of entrepreneurial optimism regardless of the personal traits of the entrepreneurs. It is obvious that only some types of people are able to accept and face the risk. The risk is a very 
common phenomenon in business, and it should be very difficult and stressful for the common people to face it. Kvietok (2013) states that only certain types of people are able to make the decision to take the risk of doing business. It is even more evident in the field of start-ups because of the higher risk level. Hvide and Panos (2014) declare that individuals who are more risk tolerant are more likely to open a start-up. Knörr et al. (2013) and Soininen et al. (2012) classified the risk taking as the personal predisposition of becoming an entrepreneur. This character trait is also considered as the entrepreneurial trait by Misra and Kumar (2002) and Sharma, Boyatzis and Jain (2011). Ključnikov et al. (2013) highlight that only entrepreneurs with high risk tolerance and specific personal characteristics are able to handle the entrepreneurial risks of doing business abroad. At the base of the previous studies we can conclude that the character traits do have an impact on the ability to take the risk, along with the other factors, such as the gender or level of education. Belás et al. (2015) confirms that the gender of the entrepreneur and the level of education do not belong to the significant factors in relation to the approach of the SME entrepreneurs to financial risk management in the environment of the Czech companies.

Creativity was the next observed character trait. Bujor and Avasilcai (2016, p. 25) wrote that according to the Austrian economist Joseph Schumpeter (2012) the entrepreneur is someone who is able to "convert a new idea or invention into a successful business."

Creativity and the ability to bring a new idea are of the needed personal traits of entrepreneurs. Knörr et al. (2013) and Almeida et al. (2014) confirm this statement. Almeida (2014) declared that the entrepreneurial individuals are characterized as enterprising and creative with some degree of social and investigative skills. This character trait is considered for entrepreneurial trait also by Misra and Kumar (2000) and by Sharma, Boyatzis and Jain (2011)

The ability to solve a problem and make a decision were the last observed character traits. Tu et al. (2012) together with the other authors (Douglas, 2005; Forbes, 2005) declared that knowing and exploring how individuals decide and solve their problems is necessary. Saravathy (2001) defined the existence of two basic types of entrepreneurial decision making - causation and effectuation decision making. They described the first type of decision making as the process where the entrepreneurs rely on analysis and estimations to explore and develop exiting and potential markets. Second type of decision making uses integrated decision making and imagination to create a new market.

According to Brockner et al. (2004) future entrepreneurs may focus on the identification of opportunities and processes in business, which is an example of causational decision making process. Effectuation decision making refers to the use of creativity and imagination in developing new markets or needs of customers.

Bujor and Avasilcai (2016, p. 25) declare that entrepreneurship can be taught. "The will, skills, knowledge are some of the features that we can learn and improve through practice. Entrepreneurs go through life looking for opportunities to sell, innovate to bring value to customers and all their shareholders. The highest and hardest is to reproduce this value, the greater are their profits, and benefits." The research team and also many other authors in their studies proved that the entrepreneurs have to declare special abilities and skills that are not common for all people to be successful in business.

A large amount of literature is focused on the personal attitudes and education that helps to support entrepreneurship, but there is a lack of studies comparing the potential entrepreneurs and common people, focused on the differences between them. This is the reason to consider this study to be rewarding for academic research and economy practice. 


\section{Research Methodology and Scientific Methods of Survey}

This part of the paper contains information about the scientific methods used in our research, about the way of data collection, the characteristics and size of the data sample, and information about alternative working hypotheses.

The research focused on the obstacles in starting business organised in cooperation with the Association of Young Entrepreneurs in Slovakia was performed in 2012 as a national research in Slovakia. The data were collected by an online questionnaire, so the choice of respondents was stochastic. The questionnaire was also placed on the specialized economic web-portals, focused on SMEs. The respondents were divided into two groups - the first one included young people who presented a potential to become the entrepreneur $(n=908)$, and the second group contained young entrepreneurs up to 34 years old $(n=325)$. This paper is focused on the first observed group young people with the age up to 34 years that had ae entrepreneurial potential $(n=908)$. According to the calculated sample the research team assumes that the data are representative, and have the reliability of $95 \%$. The sampling error of $+/-5 \%$ should be considered. The minimum size of the sample should be calculated according to the formula $\left.n=(Z)^{2} \times p \times q\right) / 0,05^{2}$ where $p$ and $q$ is the share of the sample and $\mathrm{Z}$ for $95 \%$ reliability is 1.96 . The size of the minimum sample was 384 , while the real size of our sample was $908.71 .48 \%(n=649)$ of respondents $(46.84 \%$ of them were male and $53.16 \%$ female) declared that they plan to become an entrepreneur in the future. $28.52 \%$ of the respondents $(n=259)$ stated that they don't want to do a business in the future $(21.52 \%$ of them were male and $78.48 \%$ female).

Formulation the Survey Hypotheses

Microsoft Excel (Office 2007) and its possibilities in data processing (pivot tables) were used for the analysis of the researched data. The tools of descriptive statistics (averages and percentage) were the important instruments of the research. The methods of comparison and deduction were used for the data analysis. The statistical method of Pearson's chi-square at the significance level of $5 \%$ was applied by using the statistical software available at www.socscistatistics.com for the verification of the existence of the statistically significant dependences and differences between the selected factors. If the calculated p-value was lower than 5\%, the null hypothesis was rejected, and the alternative hypothesis was adopted. Due to the length limitations the paper presents the results of the selected problems. The arguments we constructed using the method of expert estimation.

The research team compared the following character traits of the respondents from the group of potential entrepreneurs and their counterparts:

- $\quad$ Ability to accept and face the risk

- $\quad$ Creativity and new ideas

- $\quad$ Ability to solve a complex task

The authors defined four working alternative hypothesis $(\mathrm{H} 1$ - H3) for each of chosen character trait, the accuracy of which was verified by the statistical methods.

H1: Young people who want to become an entrepreneur are willing to face the risk much more intensively than others. We assume this character trait is one of the most important for the entrepreneurs.

H2: Potential entrepreneurs are statistically significantly more creative than young people without entrepreneurial ambitions. We assume that creativity is an essential character trait of the entrepreneurs, who are forced to be creative in solving problems and finding interesting solutions. 
H3: Future young entrepreneurs are more confident, more capable to solve complex tasks in comparison with other young people. They have to face more tasks, problems and challenges they are confronted with and they have to believe they can do it.

\section{$3 \quad$ Results and Discussion}

The ability to face and accept the risk was the first observed character trait. Table 1 presents the obtained results. We assumed that this character trait is a typical personal trait of the entrepreneurs. Since they do business in permanently changing environment and they have to be able to face the business risks. Potential entrepreneurs $(65.18 \%)$ are willing to accept and face the risk almost twice as likely as other young people $(37.45 \%)$. These results allow us to confirm alternative working hypothesis Hl with $99 \%$ level of probability $\left(\chi^{2}=\mathbf{8 9 . 2 9 0 3}=\chi^{2} \mathbf{0 , 0 1}\right.$ with $\left.2 \mathbf{d g f}^{2}\right)$. $P$-value is < 0.00001 .

Tab.1: Pearson's chi-square calculation

\begin{tabular}{|c|c|c|c|c|c|c|c|c|}
\hline \multirow{2}{*}{$\begin{array}{l}\text { There is } \\
\text { no } \\
\text { problem } \\
\text { for me to } \\
\text { take risks }\end{array}$} & \multicolumn{2}{|c|}{ Disagree } & \multicolumn{2}{|l|}{ Agree } & \multicolumn{2}{|c|}{ Don't know } & \multicolumn{2}{|l|}{ Total } \\
\hline & $\%$ & $\begin{array}{l}\text { absolute values } \\
\text { (AV) and chi- } \\
\text { square subtotals }\end{array}$ & $\%$ & $\begin{array}{l}\text { absolute values } \\
\text { and chi-square } \\
\text { subtotals }\end{array}$ & $\%$ & $\begin{array}{l}\text { absolute } \\
\text { values and } \\
\text { chi-square } \\
\text { subtotals }\end{array}$ & $\%$ & AV \\
\hline PYE* & 23.11 & 151(204.10)[13.81] & 65.18 & $423(364.14)[9.51]$ & 11.56 & $75(80.76)[0.41]$ & 100.00 & 649 \\
\hline OYP** & 49.03 & $127(73.90)[38.15]$ & 37.45 & 73(131.86)[26.27] & 13.51 & $35(29.24)[1.13]$ & 100.00 & 235 \\
\hline Total & - & 278 & - & 496 & - & 110 & 100.00 & $884^{3}$ \\
\hline
\end{tabular}

Source: own processing

* Potential young entrepreneurs

**Other young people

The results of the study are conformal with the opinions of such experts as Misra and Kumar (2000) and Sharma, Boyatzis and Jain (2011) who consider risk-taking as one of the most important character trait of the entrepreneurs. It should be very difficult and stressful to face the risk for common people. This fact was also confirmed by Kvietok (2013) who stated that only a specific type of people is able to make the decision to take the risk of doing business, which is more evident for start-ups due to the higher risk level. Hvide and Panos (2014) declared that individuals who are more risk tolerant are more likely to start-up firms.

Creativity and ability to bring new ideas was the second observed character trait that should be specific for the entrepreneurs. The research team supposed that potential young entrepreneurs will be more creative than other young people. The value of Pearson's chi-square statistic was $\chi^{2}=$ 63.7899 $=\chi^{2} 0,01$ with 2 dgf. This result allows us to confirm alternative working hypothesis H2. The level of probability was $99 \%$ and $p$-value is < 0.00001 . Chi-square calculation confirms that there are statistically significant differences in the level of creativity between potential young entrepreneurs and other young people. Potential entrepreneurs are statistically significant more often more creative than other young people because they are forced to be creative in problems solving and identification of interesting solutions.

The results of the research confirm that potential entrepreneurs are statistically significantly more creative than other people. This finding agrees with the opinion of Bujor and Avasilcai (2106) and

\footnotetext{
${ }^{2}$ Degrees of freedom

${ }^{3}$ Grand total in chi-square calculation
} 
Schumpeter (2012) who defined the entrepreneur as someone who is able to "convert a new idea or invention into a successful business." The results are also conformal with Knörr et al. (2013) and Almeida et al. (2014) who confirmed this statement, and Almeida (2014), Misra and Kumar (2000) and Sharma, Boyatzis and Jain (2011) who agreed that creativity is an important character trait of the entrepreneurs.

Alternative working hypothesis H3 was focused on the ability to solve complex tasks. The research team again assumed that this ability is an important character trait for future entrepreneurs. This assumption was confirmed. Ability to solve complex tasks was marked as a character trait for 90.76 $\%$ of the potential entrepreneurs. It is by $10.84 \%$ more than in case of other young people. The differences between these two groups are statistically significant. The value of chi-square statistic was $\left(\chi^{2}=\mathbf{2 9 . 9 8 2 4}=\chi^{2} 0,01\right.$ with 2 dgf). This result allows us to confirm alternative working hypothesis $H 3$ at the level of probability of $99 \%$. P-value is $<0.00001$.

The research team proved that not every young man has a potential to become and an entrepreneur in general because their character traits are different and some people do not have personal characteristics suitable to become an entrepreneur. This scientific outcome is very important for economic practice in Slovak Republic. It is linked to the alarming issue of young people's unemployment, one of the substantial problems of the European Union and Slovakia. According to Eurostat youth unemployment rate was at the level of $33.7 \%$ in 2013, and and decreased on the level of $29.7 \%$ in 2014, while the average EU level was just $23.7 \%$ in 2013 and $22.2 \%$ a year later. Slovakia declares the tendency to support young unemployed people to start their own business. The general support system does not evaluate whether all of the thousands of young unemployed people are suitable candidates for doing business. Basically every person can start doing business if he wants to. Our results indicate that the state support should be focused on people with interesting business ideas and whose personal profile matches the ones of the potential entrepreneur. We think that is the way how to effectively provide the state support for young entrepreneurs.

\section{CONCLUSION}

The research results proved that the abilities and personal traits of the entrepreneurs are different in comparison with other young people. These findings, that are conformal with a large number of scientific studies presented in literature review, allows us to confirm that such specific character traits as the creativity, ability to face a risk, ability to solve a tasks and changing risk is more typical for young entrepreneurs in comparison with other members of the society. By the tools of Pearson's chi-square statistic we proved this fact at $99 \%$ level of probability for all observed character traits. These evidence might be interesting and suggestive for policy makers. While comparing chosen character traits and their occurrence among young potential entrepreneurs and other young people we found that potential entrepreneurs are significantly different. This fact indicates that general broad-based state support in starting new business might have insufficient effectivity, and its narrowing for the people who meet certain requirements might be effective.

The strength of the presented research is in the homogeneity of the sample in comparison with the basic data set and the size of the sample. The research has some limitations. The most important limitation is the fact that the respondents fulfilled the questionnaire online, and the research team was unable to organize a more detailed face to face interview. The next limitation was the territorial focus of the research and the size of the sample. The future direction of the presented research will be focused on a comparative analysis of the entrepreneurial perception of financial and credit risks in a wider geographical area of the countries of V4. 


\section{ACKNOWLEDGMENT}

This research paper was funded from the project titled "Financing of young entrepreneurs and innovative companies with focusing on venture and private equity capital in Slovakia and EU" in the frame of the granting program of the Grant Agency of the Academic Alliance under the Grant agreement number 3/2016 and internal grant of Pan-European University in Bratislava named "Financing of innovative SMEs in Slovakia with focusing on investor's money with following comparison financing of innovation in European union."

\section{REFERENCES}

Almeida, P. I. L., Ahmetoglu, G., Chamorro-Premuzic, T. (2014). Who Wants to Be an Entrepreneur? The Relationship Between Vocational Interests and Individual Differences in Entrepreneurship. Journal of Career Assessment. 22(1). Pp. 102 - 112. DOI: 10.1177/1069072713492923.

Belás J., Korauš M., Kombo F., Korauš A. (2016) Customer satisfaction and electronic banking security in commercial banks. Journal of Security and Sustainability Issues, International Entrepreneurial Perspectives and Innovative Outcomes, 3(9), pp. 411-422. DOI:10.9770/jssi.2016.5.3(9)

Belás, J., Ključnikov, A., Vojtovič, S., Sobeková-Majková, M. (2015). Approach of the SME Entrepreneurs to Financial Risk Management in Relation to the Gender and Level of Education. Economics \& Sociology, 8(4), pp. $32-42$

Belás, J. et al. (2013). Řizení úvěrového rizika SME. Žilina: Georg.

Brockner, J., Higgins, E. T., \& Low, M. B. (2004). Regulatory focus theory and the entrepreneurial process. Journal of Business Venturing, 19, 203-220.

Bujor, A., Avasilcai, S. (2016) The Creative Entrepreneur: A Framework of Analysis. Procedia Social and Behavioral Sciences, Volume 221, 7 June 2016, Pages 21-28, 13th International Symposium in Management: Management During and After the Economic Crisis doi:10.1016/j.sbspro.2016.05.086

Deáková, K., Drážovská, K., Grznárik, D., Kondášová, I. (2010). Entrepreneurship. Bratislava: SOPK.

Delgado-García, JB; Rodríguez-Escudero, AI; Martín-Cruz, N. (2012) Influence of Affective Traits on Entrepreneur's Goals and Satisfaction. Journal of Small Business Management. 50, 3, 408-428.

Dobrovič J., Korauš A., Dančišinová L. (2016) Sustainable economic development of Slovakia: Factors determining optimal tax collection. Journal of Security and Sustainability Issues, International Entrepreneurial Perspectives and Innovative Outcomes, 5(4), pp. 533-544. http://dx.doi.org/10.9770/jssi.2016.5.4(8)

Douglas, D. (2005). The human complexities of entrepreneurial decision making: A grounded case considered.International Journal of Entrepreneurial Behavior and Research, 11(6), 422-435.

Esfahani, AN; Pour, MS. (2013) Effects of Entrepreneurial Characteristic of Public and Private Tehran School Principals on Evaluation of Innovativeness. Procedia Social and Behavioral Sciences. 93(1), 1736-1743.

Eurostat statistcis: http://ec.europa.eu/eurostat/statistics-

explained/index.php/File:Table_1_Youth_unemployment,_2014Q4_(\%25).png

Forbes, D. P. (2005). The effects of strategic decision making on entrepreneurial self-efficacy.

Entrepreneurship Theory \& Practice, 29(5), 599-626.

Frese, M., Gielnik, M. M. (2014). The Psychology of Entrepreneurship. Annual Review of Organizational Psychology and Organizational Behavior, Vol. 1, 413 - 438. DOI 10.1146/annurevorgpsych-031413-091326. 
Hvide, H.K., Panos, G. A. (2014). Risk tolerance and entrepreneurship. Journal of Financial Economics, 111, 200 - 223.

Ključnikov, A., Junger, R (2013). Barriers for foreign direct investments in Belarus: Case of business logistics. In: Proceedings of Carpathian Logistics Congress 2013. Kraków: TANGER, 2014. S. 139-145. ISBN 978-80-87294-50-5

Knőrr, H., Alvarez, C., Urbano, D. (2013). Entrepreneurs or employees: a cross-cultural cognitive analysis. Int Entrep Manag J.,9, 273 - 294. DOI: 10.1007/s11365-012-0235-2.

Korauš, A., Kiseláková, D., Demjan, V., Cibák, L. (2015) Recent Trends, Characteristics and Prospect of Payment Cards in the Slovak Republic from the Perspective of Clients. Proceedings of the 7th International Scientific Conference Finance and Performance of Firms in Science, Education and Practice, pp, 690-700, Tomas Bata University in Zlín, ISBN 978-80-7454-482-8.

Košičiarová, S. Vincúrová, Z. (2015) Register of financial statements as instrument of transparency in financial administration, Economic annals-XXI. - ISSN 1728-6220 ; 1728-6239 (online). - No. 155 (11-12) (2015), p. 117-120.

Kozubíková, L., Belás, J., Bilan, Y., Bartoš, P. (2015) Personal characteristics of entrepreneurs in the context of perception and management of business risk in the SME segment, Economics and Sociology, 8(1), 41-54 DOI: 10.14254/2071- 789X.2015/8-1/4

Kvietok, A. (2013). Psychological profile of the entrepreneur. Retrieved March 24, 2014, from http://www.psyx.cz/texty/psychologickyprofi lpodnikatele.php

Misra, S., Kumar, E. S. (2000). Resourcefulness: Approximal conceptualization of entrepreneurial behaviour. The Journal of Entrepreneurship, 9(2), 135-154.

Mura, L. Machová, R. (2015) Evaluation of the Innovation Performance of Business Networks. CERS 2014: 5TH CENTRAL EUROPEAN CONFERENCE IN REGIONAL SCIENCE, INTERNATIONAL CONFERENCE PROCEEDINGS, pp. 634-642, 2015. ISBN 978-80-553-20151

Sarasvathy, S. D. (2001). Causation and effectuation: Toward a theoretical shift from economic inevitability to entrepreneurial contingency. Academy of Management Review, 26(2), 243-288.

Sharma, R; Boyatzis, R; Jain, R. (2011) Entrepreneurial Competencies. Vision: The Journal of Business Perspective. 15, 2, 127-152.

Schumpeter, J. A. (2012). Capitalism, Socialism and Democracy. Routledge

Sidik, G. I. (2012). Conceptual framework of factors affecting SME development: Mediating factors on the relationship of entrepreneur traits and SME performance. Procedia Economics and Finance4, 373 - 383. DOI 10.1016/S2212-5671(12)00351-6.

Sobekova-Majkova, M., Solik, J., Sipko, J. (2015) Problems with financing of SMEs as one of the business risks in the conditions of Slovakia. 7th International Scientific Conference on Finance and Performance of Firms in Science, Education and Practice Location: Zlin, Czech Repbulic, April 2324, 2015, pp.1374-1389

Soininen, J., Martikainen, M., Puumalainen, K., Kyläheiko, K. (2012). Entrepreneurial orientation: Growth and profi tability of Finnish small- and medium-sized enterprises. Int. J. ProductionEconomics. 140, 614-621. DOI: 10.1016/j.ijpe.2011.05.029.

Soomro, B. A., Shah, N. (2015) Developing attitudes and intentions among potential entrepreneurs. Journal of Enterprise Information Management , 28(2), 304-322.

Tu, Ch., Hwang, S-N, Chen, J-S, Chang, F-Y.(2012) The Joint Effects of Personal and Relationships Characteristics on Micro-Entrepreneurial Success. Procedia Economics and Finance, January 2012, 4(1), 365-372. 